Le nka Krátká

[Praga, Republika Czeska]

\title{
„Byłem ciekawy, czy morze jest słone!” \\ Czechosłowacka Żegluga Morska we wspomnieniach marynarzy czechosłowackich (1959-1989)
}

Wrocławski Rocznik Historii Mówionej Rocznik III, 2013 ISSN 2084-0578

\section{„RODZIMY” PORT SZCZECIN}

Z własnego doświadczenia wiem, że podczas rozmów z (byłymi) marynarzami czechosłowackimi prędzej czy później pojawi się w ich wspomnieniach wzmianka o żegludze morskiej w Polsce. Powodów tego skojarzenia jest kilka. Przede wszystkim polskie porty, Gdynia, Gdańsk i Szczecin (tutaj szczególnie często wspominane nabrzeże Ewa), przez cały okres istnienia Czechosłowackiej Żeglugi Morskiej służyły jako swego rodzaju „rodzime” porty statków czechosłowackich. W niektórych przypadkach także polscy marynarze (chodziło najczęściej o niższych oficerów) stanowili część załóg czechosłowackich statków morskich, przede wszystkim w początkach żeglugi morskiej w Czechosłowacji, po II wojnie światowej. Co więcej, wielu byłych marynarzy czechosłowackich, szczególnie oficerów i kapitanów, studiowało w szkole morskiej w Szczecinie (dziś Akademia Morska w Szczecinie, przez świadków nazywana Państwową Szkołą Morską).

Cytat z rozmowy z marynarzem 1 klasy Jánem Jurcem, który przeprowadziła Lenka Krátká, 22 III 2010 r. Prywatne archiwum autorki. 
Udokumentowane są na przykład wspomnienia kapitana żeglugi dalekomorskiej - Antonina Fojtů, który ukończył szkołę w 1950 r. i w swych pamiętnikach wspomina dyrektora Macierewicza: „Nazywany przez studentów Macaj, był dla nas prawdziwym wzorem. Starał się aplikować nam wiedzę we właściwych proporcjach teorii i praktyki - obie są niezbędne marynarzowi. [...] Swoją karierę Macaj zaczynał w carskiej marynarce wojennej. [...] Jako dowódca polskich statków szkolnych, najpierw Lwowa, a potem Daru Pomorza, zdobył sobie zaufanych ludzi [...] Każdy wiedział, że to, czego uczy studentów, sam opanował perfekcyjnie"2. Osobiste świadectwo o studiach w tej samej szkole dał także kapitan żeglugi dalekomorskiej Milan Rusňák ${ }^{3}$. W szkole czekała ich ciężka praca i dyscyplina, ale nie żałowali swojej decyzji: „To była ciągła harówka. Bo w międzyczasie mieliśmy praktyki w lecie na tym statku szkolnym, gdzie ta nauka trwała nadal" ${ }^{\text {. }}$ Bez dalszych badań archiwalnych nie można z całą pewnością stwierdzić, w ramach jakiej inicjatywy czy współpracy międzynarodowej przyjmowano Czechosłowaków do wspomnianej szkoły. Niemniej wpływ polskiej tradycji morskiej na marynarzy czechosłowackich jest niekwestionowany.

Myślę, że ze względu na powyższe związki artykuł o marynarzach czechosłowackich znajdzie swoich czytelników i czytelniczki także w polskim periodyku. W niniejszym tekście przedstawię projekt poświęcony tematowi historii przedsiębiorstwa Czechosłowacka Żegluga Morska, który realizowałam przy udziale siedemnastu marynarzy czechosłowackich metodą oral history. W części pierwszej przybliżę kontekst historyczny pracy (a więc historię żeglugi morskiej w Czechosłowacji po II wojnie światowej) oraz wybrane aspekty metodologiczne pracy $\mathrm{z}$ wykorzystaniem metody oral history. W drugiej części tekstu przedstawię niektóre fragmenty zrealizowanych przeze mnie wywiadów oral history. Interpretacja tych źródeł będzie prowadzona dwubiegunowo: $\mathrm{z}$ jednej strony świat publiczny, a z drugiej prywatne życie rodziny, a wszystko to zostanie osadzone w kontekście epoki przed $1989 \mathrm{r}$.

2 A. Fojtů, Moře milované, moře proklínané. Čast 1., Praha 2006, s. 9.

3 Rozmowę z Milanem Rusňákiem przeprowadziła Lenka Krátká, 22 XI 2010 r. Prywatne archiwum autorki.

4 Ibidem. 


\section{Krótka historia czecho- słowackiej Żeglugi Morskiej}

Mniej więcej w tym samym okresie, kiedy wspomniani kapitanowie kończyli polską szkołę morską, powstał plan stworzenia przedsiębiorstwa Czechosłowacka Żegluga Morska (Československá námořní plavba - ČNP). Pierwsze ślady powojennej ${ }^{5}$ żeglugi morskiej Czechosłowacji pochodzą w przybliżeniu z 1951 r., kiedy zakupiono statek Republika I'. W trakcie swego pierwszego rejsu został on zniszczony przez tajfun i do 1953 r. był naprawiany w stoczni w Szanghaju. W tym samym roku podpisano Protokót o rozwoju transportu morskiego między Republiką Czechosłowacką a Chińską Republika Ludową, na którego podstawie chiński partner użytkowat swoje statki - będace formalnie wtasnością czechosłowacka - pod czechosłowacka banderą ${ }^{7}$ W 1959 r. założona została międzynarodowa spółka akcyjna Czechosłowacka Żegluga Morska, w której 51\% akcji było własnością Republiki Czechosłowackiej, reszta - Chińskiej Republiki Ludowej ${ }^{8}$. Pod koniec lat 6o. XX w. współpraca ta została zakończona. Wszystkie istotne źródła jasno sugerują, że ČNP była założona nie tylko z powodów czysto

5 Międzywojenna historia żeglugi morskiej w Czechosłowacji nie wchodzi w zakres tematyczny opracowania, jednak warto wspomnieć tu eksploatację statku Legie w 1920 r., zakupionego przez praski bank Legiobanka (Banka československých legií - przyp. tłum.) z przeznaczeniem do handlu z Dalekim Wschodem (J. Machota, Československo na mořich a oceánech, Praha 1989, bez paginacji).

6 Problematyka powstania przedsiębiorstwa będzie szczegółowo opracowana w ramach dysertacji autorki. W tym miejscu należy jedynie wspomnieć, że dostęp do morza po rozpadzie monarchii Habsburskiej zapewniły nowopowstałej Republice Czechosłowackiej ustalenia Wersalskiego Traktatu Pokojowego, a konkretnie artykuły 363 i 364, które gwarantowany dostęp do portów Hamburg i Szczecin (Peace Treaty of Versailles. Articles 321-386. Ports, Waterways and Railways, <http://net.lib. byu.edu/ rdh7/wwi/versa/versa11.html> (dostęp: 27 XII 2012 r.).

7 Z. Bastl, Padesát let Československé námořní plavby, Praha 2009, s. 9.

8 Chińska Republika Ludowa obchodziła w ten sposób izolację międzynarodową, ponieważ „Stany Zjednoczone odmówiły uznania nowego chińskiego reżimu (państwo komunistyczne Chińska Republika Ludowa - przyp. autorki) i wetowały wymianę chińskiego ambasadora w radzie bezpieczeństwa. Chiny były więc w organizacji światowej (ONZ - przyp. autorki) aż do początku lat 7o. reprezentowane przez rząd kuomintanski Tajwanu"; B. Plechanow, J. Fidler, Kapitoly z dějin mezinárodních vztahů 1941-1995, Praha 1997, s. 67). W związku z izolacją międzynarodową Chińska Republika Ludowa nie mogła oficjalnie eksploatować statków morskich pod własną banderą. 
ekonomicznych, ale też że jej powstanie było w sposób zasadniczy związane $\mathrm{z}$ międzynarodową sytuacją polityczną, a przede wszystkim z przynależnością Czechosłowacji do strefy wpływów Związku Radzieckiego.

ČNP rozwijała się i w 1989 r. eksploatowała już dwadzieścia statków morskich. W 1992 r. została objęta pierwszą falą prywatyzacji kuponowej. Jednocześnie rozpoczęto zakładanie spółek-córek (Malta, Cypr), którym przekazano pojedyncze statki (przede wszystkim z powodu ulg podatkowych i możliwości łatwiejszego uzyskania kredytów zagranicznych). W $1994 \mathrm{r}$. zmieniono nazwę spółki na Czeska Żegluga Morska [Česká námořní plavba - przyp. tłum.], na podstawie rozliczeń majątkowych po rozpadzie Czechosłowacji 1 stycznia 1993 r.). W 1995 r. firma została kupiona przez grupę związaną z Funduszami Harwardzkimi Viktora Koženego. Powstają kolejne spółki-córki, które następnie stopniowo odsprzedają statki (za cenę niższą niż wartość rezydualna czy rynkowa), na podstawie decyzji swoich walnych zgromadzeń, bez głosu kierownictwa ČNP (Praga), które jest traktowane jedynie jako spółka menedżerska?.

Wraz z odsprzedaniem ostatniego statku Jan Želivský ${ }^{10}$ w 1998 r. dochodzi do faktycznej likwidacji Czeskiej Żeglugi Morskiej. Źródła do tego tematu podlegają archiwalnemu okresowi ochronnemu 30 lat, a sama historia ČNP jest zagadnieniem rozległym, dlatego niniejsze badania oral history dotyczą jedynie okresu do 1989 r., a więc do czasu radykalnej zmiany warunków społecznych, politycznych, socjalnych i ekonomicznych, które wpłynęły także na funkcjonowanie ČNP. Za historią przedsiębiorstwa „kryją się” natomiast prywatne historie pojedynczych ludzi, konkretne losy marynarzy i ich rodzin.

\section{Metoda oral history jako jedna z dróg badań historycznych}

W badaniach nad prezentowanym tematem najbardziej pomocna okazała się metoda oral history. Przed 1989 r. temat Czechosłowackiej Żeglugi Morskiej był opracowywany jedynie $\mathrm{w}$ formie publikacji edukacyjnych ${ }^{11}$,

\footnotetext{
Z. Bastl, op. cit., s. 11-13.

10 Statek nazwany na cześć przedstawiciela ruchu husyckiego.

11 J. Frey, Lod', moře, námoŕníci, Praha 1961 (2. uzupełnione wydanie 1967).
} 
beletrystycznych ${ }^{12}$, popularnonaukowych ${ }^{13}$, ewentualnie albumowych ${ }^{14}$.

Teksty te zawierają wiele danych faktograficznych, a przede wszystkim technicznych o poszczególnych statkach. Nie można ich jednak uważać za opracowania naukowe - zarówno ze względu na niedostatki formalne (brak przypisów, bibliografii itd.), jak i z powodu bezpośrednio narzucającej się w nich ideologii, propagującej porządek socjalistyczny (co w wielu przypadkach sprowadza się do przemilczeń czy „upiększania” rzeczywistości - charakterystycznym przykładem może być kwestia transportu broni na czechosłowackich statkach morskich). Zniesienie cenzury, większe możliwości wydawnicze, ale wreszcie likwidacja ČNP, spowodowały „wysyp” publikacji wspomnieniowych, z charakterystycznym dla tego typu publikacji wysokim stopniem subiektywności i niewiarygodności faktograficznej. Na podobne rafy natknąć się można także w przypadku relacji świadków historii; na korzyść tego typu źródeł przemawia jednak fakt, że wywiady oral history przeprowadzane są $\mathrm{w}$ zgodzie $\mathrm{z}$ metodologicznymi, proceduralnymi, etycznymi i prawnymi zasadami tej metody ${ }^{15}$.

Mamy zatem do czynienia z problematyką, która w środowisku czeskim nie była dotąd w wystarczającym stopniu opracowana naukowo. Projekt, który poszerzy wiedzę w tym temacie, jest obecnie przygotowywany przez autorkę artykułu. Badania metodą oral history przeprowadzone z byłymi marynarzami czechosłowackimi można w tym przypadku traktować także jako jeden ze sposobów uzupełnienia źródeł pisanych. Jeżeli chodzi bowiem o zasoby źródłowe, dotyczące historii żeglugi dalekomorskiej w Czechosłowacji po II wojnie światowej, sytuacja jest daleka od satysfakcjonującej. Najbogatszy zbiór materiałów znajduje się w Archiwum Narodowym (Národní archiv) - zarówno organizacyjny spadkobierca ČNP jak i Ministerstwo Transportu twierdzą, że odpowiednie dokumenty dotyczące żeglugi dalekomorskiej przekazały temu właśnie archiwum. Zbiór ten jest jednak dotychczas nieopracowany, dlatego nie sposób stwierdzić,

12 B. Černý, Na daleké plavbě, Praha 1963; B. Stožický, S palubou pod nohama, Praha 1973; A. Jakeš, Poutník oceány, České Budějovice 1980.

13 J. Pacovský, Mořští vlci na Blaníku, Praha 1976; idem, V. Podlena, Atlas lodí, Československé námořní lod'stvo, Praha 1984.

14 J. Machota, Československo na mořích a oceánech, Praha 1989 (opublikowane także w jęz. angielskim, hiszpańskim, francuskim).

15 M. Vaněk, P. Mücke, Třetí strana trojúhelníku. Teorie a praxe orální historie, Praha 2012 . 
jakie materiały i w jakiej liczbie się w nim znajdują, jakiego dotyczą okresu, a przede wszystkim, kiedy będą udostępnione ${ }^{16}$. Archiwum Narodowego Muzeum Technicznego (Archiv Národního technického muzea) zawiera jedynie bardzo fragmentaryczne materiały dotyczące parametrów technicznych poszczególnych statków. Archiwum Wszechzwiązkowe (Archiv Všeodborových svazů) nie posiada żadnych relewantnych źródeł. Nie wiadomo, czy interesujące nas materiały znajdują się w Archiwum Ministerstwa Spraw Zagranicznych ${ }^{17}$. Cennym źródłem informacji jest Archiwum Służb Bezpieczeństwa (Archiv Bezpečnostních složek), przechowujące teczki zakładane przez dawną Służbę Bezpieczeństwa (Státní bezpečnost) poszczególnym obiektom i jednostkom. W sumie w ewidencji znaleziono jedenaście teczek obiektowych związanych z danym tematem; przetrwała jednak tylko jedna - teczka obiektowa nr 4147 II (č. 4147 II. správy). Jej zawartość jest co prawda bardzo rozległa czasowo i tematycznie, jednak zawiera informacje przede wszystkim dotyczące takich tematów, jak kontakt marynarzy z cudzoziemcami i emigrantami, nielegalny handel („paskarstwo"), przestępstwa celne.

Poza niekompletnością i słabym opracowaniem zbioru archiwalnego za wyborem metody oral history przemawia także fakt, że metoda ta umożliwia spojrzenie na opracowywany temat pod „nowym” kątem. Możemy mówić o liczbie statków, o ładunkach, trasach, $\mathrm{GRT}^{18}$, ale nic nam to nie powie o ludziach, ich przeżyciach, o tym, jak marynarze czuli się poza granicami komunistycznej Czechosłowacji, ani o ich rodzinach. Rodzina stanowi bowiem kolejną płaszczyznę badanej problematyki - rodzina, która stwarzała marynarzowi oparcie, która choć nie miała z jego pracą na morzu nic

16 Dotychczas udało się uzyskać niektóre dokumenty dotyczące początków współpracy z ChRL (skąpe informacje na temat początków współpracy można znaleźć także w zasobach Urzędu Prezesa Rady Ministrów (Úřad předsednictva vlády) w Archiwum Narodowym), wyników ekonomicznych przedsiębiorstwa i protokoły z narad dyrektorów. Ich analiza będzie częścią składową przygotowywanego projektu; nie mają one większego związku z tematem niniejszego artykułu, koncentrującego się na prywatnym i zawodowym życiu marynarzy.

17 W archiwum tym opracowanych jest tylko ok. 50\% wszystkich materiałów archiwalnych, dlatego nawet jeżeli jakieś materiały o żegludze dalekomorskiej są tam przechowywane, nie można z nich skorzystać.

18 Gross Reiter Tonnage - tona rejestrowa brutto, miara używana do wyrażenia całkowitej wewnętrznej pojemności jednostki pływającej; nie wyraża wagi ani wyporności statku. 
wspólnego, podlegała znaczącemu wpływowi wykonywanego przez mężczyznę zawodu. (Tu odwołuję się także do własnych wspomnień, bo sama pochodzę z rodziny marynarza). W ten sposób dotykamy pewnych aspektów charakterystycznych dla metody oral history. Nie będę w tym miejscu powtarzała wskazówek i wytycznych metodologicznych, które można łatwo znaleźć w publikacjach specjalistycznych, artykułach i podręcznikach, gdyż dostępna literatura (choćby w języku angielskim) jest już dziś bogata. Proponuję tu refleksję opartą na własnych doświadczeniach w pracy z narratorami, z naciskiem na to, jak na pracę badacza/badaczki wpływa jego zaangażowanie emocjonalne i w jaki sposób na opracowywany temat wpływa historia rodzinna badacza/badaczki.

W moim przypadku zaangażowanie emocjonalne $\mathrm{w}$ prowadzone badania było stosunkowo silne. W byłej Czechosłowacji, a więc w kraju bez bezpośredniego dostępu do morza i bez znaczącej historii morskiej, zawód marynarza traktowany był jako wyjątkowy. W porównaniu z większością populacji marynarze mogli podróżować za granicę, w tym także do krajów zachodnich, a wręcz po całym świecie, co dla większości obywateli było praktycznie nieosiągalne. Co więcej, marynarze mieli (a raczej umieli sobie stworzyć, o czym piszę szczegółowo w dalszej części pracy) dostęp do zagranicznych walut, a co za tym szło do niedostępnych w kraju zagranicznych towarów. Wszystko to było w tym kontekście zaletą, czy przynajmniej przyjemnym ubarwieniem życia, niemniej mogło także wywołać zawiść otoczenia, a u dzieci prowadzić do wyłączenia z grupy rówieśników i pewnego rodzaju samotności. Dodajmy do tego długotrwałą nieobecność ojca w rodzinie, konieczność reorganizacji życia w mniej więcej półrocznych odstępach, co jest również bardzo stresujące ${ }^{19}$.

Wszystkiego tego doświadczyłam jako dziecko. Jednocześnie możliwość udziału w niektórych podróżach razem z ojcem miała zasadnicze znaczenie dla mojego dalszego życia. Morze stało się nieodłączną częścią mojego życia i fakt, że w Czechosłowacji kobiety nie mogą pracować na statkach, doprowadził mnie do długotrwałej frustracji. W latach dziewięćdziesiątych mój ojciec-marynarz zmarł, a kilka lat później

19 Jeden z narratorów, którego żona była Bułgarką, w związku z tym zauważył, że mniej wyemancypowane kobiety, takie jak na przykład dziewczęta z Bałkanów, lepiej znoszą ten rodzaj życia, kiedy mąż na dłuższy czas odjeżdża i znów wraca. Rozmowę z Milanem Rusňákiem przeprowadziła Lenka Krátká, 22 XI 2010 r. Prywatne archiwum autorki. 
zlikwidowana została Czechosłowacka Żegluga Morska. W związku z podjętym projektem badawczym doświadczałam więc wielu różnych (niekiedy przeciwstawnych) uczuć.

W podobnej sytuacji znaleźć się może każdy badacz czy badaczka, i każdy powinien swój emocjonalny związek z opracowywanym tematem zdefiniować jeszcze przed rozpoczęciem pracy. Podczas kontaktów z narratorami/narratorkami nieprzepracowane emocje mogą bowiem negatywnie wpłynąć na całokształt interakcji. Z metodologicznego punktu widzenia wszystkie takie uwarunkowania trzeba mieć na uwadze przede wszystkim na etapie interpretacji rozmów, gdyż nieuświadomione zaangażowanie uczuciowe może w znaczącym stopniu pozbawić interpretację wartości naukowej.

\section{Interpretacja poszczególnych Zagadnień wywiadów}

Wróćmy teraz do samych wywiadów oral history. W okresie od lutego do listopada $2010 \mathrm{r}$. przeprowadziłam rozmowy z siedemnastoma (byłymi ${ }^{20}$ marynarzami czechosłowackimi ${ }^{21}$. Szesnastu z nich pochodziło z Republiki Czeskiej (najczęściej z Pragi, kraju środkowoczeskiego i północnoczeskiego), jeden ze Słowacji ${ }^{22}$. Z punktu widzenia hierarchii byli to w większości oficerowie: trzech kapitanów, dwóch starszych oficerów pokładowych, dwóch starszych oficerów mechaników, jeden lekarz pokładowy, jeden ekonom pokładowy; podoficerowie: jeden bosman, dwaj mechanicy wachtowi i dwaj szefowie kuchni; załoga - dwaj marynarze 1. klasy (A/B $)^{23}$. Najstarszy z narratorów urodził się w 1930 r. i w ČNP pracował czterdzieści

20 Wśród narratorów byli także tacy, którzy zawód marynarza wykonują nadal, pracując u obcych armatorów.

21 W tekście mowa jest o Czechosłowacji, Czechosłowakach itd., praca bowiem dotyczy okresu przed rozdzieleniem Czechosłowacji na początku lat dziewięćdziesiątych XX w.

22 Wybór narratorów nie był przypadkowy, chociaż ograniczony możliwościami badaczki - brak kontaktów, niekiedy złe doświadczenia potencjalnych narratorów z mediami, brak zaufania (dlaczego córka byłego marynarza robi wywiady, co w ten sposób bada, dlaczego pyta właśnie mnie itd.), niekiedy brak czasu czy po prostu chęci.

23 Oczywiście marynarze o wyższych stopniach przeszli praktykę na niższych stanowiskach służbowych, w rozmowach jednak najczęściej posługiwali się swym najwyższym stopniem. 
lat; najmłodszy narrator pracował w firmie jedynie sześć lat, a urodził się w 1964 r. Z punktu widzenia reprezentatywności wyboru udało się w końcu, mimo problemów ze skontaktowaniem się z narratorami, przeprowadzić rozmowy ze stosunkowo rozległą grupą byłych marynarzy, co więcej ze wszystkich stopni hierarchii pokładowej i wszystkich trzech załóg (pokładowej, maszynowej, gospodarczej), poza radiotelegrafistą. Szeroka rozpiętość wieku narratorów umożliwiła prześledzenie w czasie zmian w ocenie Czechosłowackiej Żeglugi Morskiej i zawodu marynarza. Poza różnicami generacyjnymi dostrzegalnymi w ich poglądach, istotną rolę odgrywało także stanowisko służbowe. Starsi narratorzy i wyżsi oficerowie w swoich wspomnieniach przykładali zazwyczaj większą wagę właśnie do swojego stanowiska, do swoich zdolności, umiejętności, doświadczenia. Od drugiej grupy, przede wszystkim podoficerów i załogi, można się było też więcej dowiedzieć o codziennym życiu marynarzy.

Jak już wspomniałam, zasadniczą oś badań wyznaczyło życie zawodowe marynarza z jednej i prywatne życie jego rodziny z drugiej strony. Z powodu pewnej, wspomnianej już, „wyjątkowości” zawodu marynarza na tle kraju, część interpretacyjną rozpoczyna temat początków ścieżki zawodowej. Stwierdzić należy, że w przypadku narratorów wybór zawodu często nie był skutkiem świadomej decyzji, ale „dziełem przypadku” (niektórzy o możliwości pracy na morzu dowiedzieli się z gazet, inni od współpasażera w pociągu, lub od kolegi, a jeszcze inni celowo szukali samorealizacji jak najdalej od domu...).

Jeżeli chodzi o przygotowanie zawodowe załogi, Czechosłowacja dysponowała własnymi specjalistycznymi szkołami, gdzie marynarze mogli zdobyć potrzebne kwalifikacje ${ }^{24}$. Odmienna była sytuacja oficerów morskich - ci mogli studiować tylko w szkołach morskich za granicą, szczególnie w krajach byłego Bloku Wschodniego. Starsi z nich studiowali w szkole w Polsce (zob. wyżej), w latach późniejszych Czechosłowacy mogli studiować przede wszystkim w Odessie (wówczas w Związku Radzieckim) ${ }^{25}$. Ich wspomnienia bardzo różnią się między sobą. Trzech absolwentów szkoły

24 Szkoła Zawodowa Czechosłowackiej Żeglugi Łabsko-Odrzańskiej w Děčinie dla załóg pokładowych, inne szkoły zawodowe o specjalności maszynowej dla załogi maszynowej.

25 Ewentualny związek między sytuacją polityczną w konkretnym okresie historycznym a dyrektywami, które wyznaczały, gdzie mogą studiować Czechosłowacy, nie jest jeszcze dostatecznie zbadany. 
w Odessie (początek studiów w latach 1962, 1968, 1972) zwraca uwagę przede wszystkim na złe warunki bytowe w ówczesnym Związku Radzieckim: „My tam przylecieliśmy, my nie wierzyliśmy własnym oczom. Kręciliśmy głowami. Było to dosłownie brutalne, ta rzeczywistośćn ${ }^{26}$. Jednocześnie nie wspominają zbytnio szkolnej codzienności czy zakresu nabytych umiejętności i doświadczeń. Z drugiej strony wspomniany już kapitan Rusňák, jeden z pierwszych absolwentów szkoły morskiej w Polsce, zwrócił uwagę na to, że studia były wymagające, jak na powojenny ustrój, ale także na jakość kształcenia tamtejszej szkoły i swoiste poczucie wyjątkowości: „No i my jako szkoła elitarna byliśmy wszędzie zapraszani. [...] Zyskaliśmy naprawdę solidne, jeszcze takie klasyczne szkolenie, tak jak należało. Więc bardzo tym Polakom dziękuję"27. W podobny sposób wyraża się w swych wspomnieniach kapitan Fojtů ${ }^{28}$.

Także dziś, kiedy żyjemy w państwie demokratycznym, a nasze możliwości podróżowania ograniczają jedynie środki finansowe i własna odwaga, Czesi wiążą zawód marynarza przede wszystkim z możliwością podróżowania po całym świecie, odwiedzania nawet tych najbardziej odległych kontynentów, przeżycia przygody. (Ten romantyczny obraz ma prawdopodobnie związek przede wszystkim z tym, że Republika Czeska jest krajem bez bezpośredniego dostępu do morza). Przez analogię założyłam, że w okresie przed 1989 r. właśnie możliwość podróżowania, co więcej podróżowania w zasadzie po całym świecie, była tym, co najbardziej przyciągało do zawodu marynarza.

Byli marynarze nie podkreślali jednak zbytnio tego czynnika. Niektórzy wprawdzie wzmiankowali, że mieli do dyspozycji tzw. stałą klauzulę wyjazdową ${ }^{29}$, uprawniającą do podróży zagranicznych (w tym do krajów zachodnich), ale traktowali ją jako niezbędną część swojej pracy, niektórzy jako swego rodzaju „symbol statusu”, a nie jako przywilej w porównaniu $\mathrm{z}$ resztą populacji. Dlaczego? Odpowiedź na to pytanie przyniosła interpretacja dwóch związanych ze sobą zagadnień - emigracji i pracy na morzu.

26 Rozmowę z Jiřím Jurčíkiem przeprowadziła Lenka Krátká, 25 IV 2010 r. Prywatne archiwum autorki.

27 Rozmowę z Milanem Rusňákiem przeprowadziła Lenka Krátká, 25 IV 2010 r. Prywatne archiwum autorki.

28 A. Fojtů, op. cit.

29 Klauzula ta była wydawana „z zasady do paszportów służbowych”, „w zasadzie jedynie do celów służbowych”; J. Rychlík, Cestování do ciziny v habsburské monarchii a v Československu, Praha 2007, s. 69. 
Odnośnie do emigracji, należy zastrzec, że rozmowy były przeprowadzone wyłącznie z marynarzami, którzy nie wyemigrowali ${ }^{30}$, dlatego w efekcie wnioski są w dużym stopniu jednostronne. Z drugiej strony zapisy w dziennikach pokładowych ${ }^{31}$, które dotychczas przestudiowałam, wskazują, że emigracja była sytuacją raczej wyjątkową ${ }^{32}$. Nie jest więc zaskoczeniem, że narratorzy wyrażali się o emigracji bez wyjątku krytycznie, o ile w ogóle o niej mówili ${ }^{33}$. Jeżeli pytałam wprost, czy rozważali emigrację, wyjaśniali, że przez taki krok zaszkodziliby swoim bliskim, lub (i to wyjaśnienie było najczęstsze), że z perspektywy czasu dostrzegają, że nie mieli powodu, by emigrować: „Gdybym wyemigrował, nie zobaczyłbym tylu krajów. Przecież odwiedziłem pięćdziesiąt cztery państwa. Czego mi więc brakowało? To trzeba zostawić. A co, mógłbym odjechać z rodziną? Sam być daleko? Nie, nie"34.

W związku z tematem emigracji pojawiał się w rozmowach jeszcze jeden ważny motyw - potrzeba domu, możliwości powrotu do domu: „Jestem przyzwyczajony, kiedy przyjadę do domu, iść do tej gospody, tam spotkać znajomych, kolegów... A potem jest wieś, do której zawsze najpierw jadę, kiedy przyjadę z morza, gdzie się urodziłem. Żona zawsze mówi: «No tak, jak nie pojedziesz do Sudkova, to jak byś nie był w domu, co?» A tam nie mógłbym wracać"35. W jednym przypadku narrator przyznaje wręcz, że przekonywał swoją żonę, która chciała wyemigrować, by rodzina została w Czechach: „Krótko mówiąc kombinowałem, jak zniechęcić żonę, nie chciałem emigrować. Powiem pani. Mówiłem sobie, niby dlaczego? Mam pracę, zarabiam jak na warunki czechosłowackie tamtego czasu nawet

30 Z emigrantami nie udało się skontaktować.

31 Národní archiv, fond Československá námořní plavba, nieopracowany.

32 Wyjątek stanowi na przykład przypadek statku Brno, którego w okresie od 21 do 31 sierpnia $1968 \mathrm{r}$. jedenastu marynarzy poprosiło o azyl we włoskim porcie Bari, w tym pięciu z małżonkami, wraz z trójką dzieci (Národní archiv, Praha. Fond Československá námořní plavba, nieopracowany, Lodní deník Brno, č. 12 a 13).

$33 \mathrm{~W}$ interpretacji wywiadów oral history to, o czym się nie mówi, jest często równie znaczące jak tematy, które się w rozmowie pojawiają; M. Vaněk, P. Mücke, H. Pelikánavá, Naslouchat hlasům pamětí. Teoretické a praktické aspekty orání historie. Praha 2007, s. 66-70.

34 Rozmowę z Janen Kurką przeprowadziła Lenka Krátká, 12 XI 2010 r. Prywatne archiwum autorki.

35 Rozmowę z Vladimírem Skoumalem przeprowadziła Lenka Krátká, 8 V 2010 r. Prywatne archiwum autorki. 
dobre pieniądze. Nie chciałem emigrować. Bo, jak mówię, od młodości kocham Góry Izerskie, kiedy jestem teraz w domu, jestem tam dwa albo trzy razy w tygodniu. Straciłbym to. Więc trzeci raz odmówiłem, no i potem już nikt mnie do przekonywał do emigracji" ${ }^{\prime 36}$.

Istnieje jeszcze jeden motyw, który pomoże nam zrozumieć, dlaczego narratorzy nie „cenili” sobie zbytnio możliwości podróżowania i dlaczego nie czuli potrzeby emigracji - była to ich praca, ich zawód marynarza. Wszyscy narratorzy, choć każdy w inny sposób, wyrażają dumę ze swego zawodu, zwłaszcza dumę z tego, że byli zdolni pracę marynarza (często przez długie lata) wykonywać. Nie zwracają zbytnio uwagi na ciężkie warunki na statku (ciężka praca fizyczna, rozłąka z rodziną, izolacja społeczna, ekstrema klimatyczne, silne i długotrwałe sztormy czy podróże w niebezpieczne miejsca) ${ }^{37}$, ale podkreślają obciążenia zawodu marynarza i swoją wysoką pozycję zawodową: „I muszę tu powiedzieć, [...] że nigdzie się u nas nie tyrało tak jak na statku. To naprawdę, gdyby wtedy wszyscy tutaj tyrali tak, jak na statku, to byśmy już dawno ten komunizm zbudowali" ${ }^{38}$. Obok dokonań zawodowych akcentują także swoją miłość do morza, którą niektórzy przyrównują nawet do uzależnienia: „Czyste powietrze. Morska bryza. Rano, kiedy szedłem o czwartej na służbę, morska bryza, wiatr, czułem to ciepłe morskie powietrze, powiew, oddychało się tam cudownie. To ma swoje zalety. Człowiek przyzwyczaja się do tego, że to kochał i że jest tam szczęśliwy i nie chce do domu [...] To było trochę jak narkotyk. Bo, prawda, ludzie ciągle tam, prawda, wracają. Wracają"

36 Rozmowę z Milanem Bláhou przeprowadziła Lenka Krátká, 26 V 2010 r. Prywatne archiwum autorki.

37 Trzeba zwrócić uwagę, że o czechosłowackich marynarzy zawsze bardzo się troszczono. Otrzymywali bezpłatne ciepłe posiłki trzy razy dziennie (w tym zupa i ciasto w południe; przystawka wieczorem), dostęp do zimnego bufetu, w tym kawa i herbata 24 godziny na dobę. Na starszych statkach kwaterowano załogę po dwie osoby, a pomieszczenia socjalne były wspólne; na nowszych statkach kajuty były już samodzielne z zapleczem. Bieliznę pościelową wymieniano raz na dwa tygodnie, ręczniki raz w tygodniu. Marynarze otrzymywali bezpłatne mydło i ochronne pomoce robocze. Z drugiej strony jednak w niektórych przypadkach na statku nie było lekarza, co w pewnych okolicznościach mogło mieć fatalne skutki.

38 Rozmowę z Petrem Krouřilem przeprowadziła Lenka Krátká, 9 V 2010 r. Prywatne archiwum autorki.

39 Rozmowę z Jánem Jurcem przeprowadziła Lenka Krátká, 22 III 2010 r. Prywatne archiwum autorki. 
O znaczeniu, jakie miała dla marynarzy ich praca i życie na morzu, bez względu na to, dokąd statek płynął, mówi również analiza ich życia prywatnego.

\section{„Było coś za coś"4o - prywatne życie marynarzy kontra ich praca}

Pozwolę sobie w tym miejscu na małą dygresję, która w pewnym stopniu nawiązuje do metodologicznej części niniejszego tekstu. Otóż, początkowo moim założeniem badawczym było spojrzenie na temat żeglugi morskiej w Czechosłowacji oczyma żon i dzieci byłych marynarzy, co w znacznym stopniu motywowane było potrzebą refleksji nad własnym doświadczeniem. Byłam przy tym świadoma, że właśnie rodziny marynarzy są w świetle tego tematu tą najbardziej „niewidzialną” grupą, a poznanie ich losów może temat w zasadniczy sposób ubogacić. Niestety nie udało się zrealizować tego zamiaru. Odnalezienie i skontaktowanie się z żonami i dziećmi było jeszcze trudniejsze niż z samymi marynarzami, co więcej żony do których dotarłam kategorycznie odmawiały rozmowy. Ich reakcje mogły świadczyć o tym, że albo nie uważają swojego życia i samych siebie (w porównaniu z mężem-marynarzem) za wystarczająco interesujące, aby wziąć udział w projekcie, albo że bardzo niechętnie wspominają swoje życie z czasów, kiedy mąż na długie okresy wyjeżdżał na morze ${ }^{41}$.

Prowadząc rozmowy z marynarzami, nie zrezygnowałam jednak do końca ze swego pierwotnego zamysłu - nieodłączną częścią wywiadów był krąg pytań o to, jak narratorzy z perspektywy czasu widzą nie tylko własne życie w oddaleniu od rodziny, ale przede wszystkim, jak postrzegają ówczesną sytuację swoich rodzin. Jeśli emigracja była tematem, o którym mówili mało, to dwukrotnie mniej mówili o problematyce życia rodzinnego. Nie tylko żaden $\mathrm{z}$ nich spontanicznie nie przywołał tego tematu; nawet na konkretne pytanie odpowiadali bardzo wymijająco i zwięźle, a w jednym przypadku narrator wręcz zignorował pytanie (nie chodziło tu o niedosłyszenie).

Dlaczegotak reagowali? Czy oznacza to, że nie myśleli o swoich rodzinach? Nie byli świadomi problemów, które stwarzała długotrwała nieobecność

40 Ibidem.

41 Więcej na ten temat L. Krátká, Ženská na lod’ nepatří. Dimenze gender ve vzpomínkách bývalých československých námořníků, [w:] Mezi obzory. Gender v interdisciplinární perspektivě, red. B. Knotková-Čapková, Praha 2011, s. 21-41. 
mężczyzny w rodzinie? Nie interesowało ich to? Jest mało prawdopodobne, by wszyscy narratorzy byli tak niewrażliwi (nie jest prawdopodobne, żeby tak bezwzględny był choćby jeden z nich). Co więcej, niektóre wypowiedzi sugerują, że uświadamiali sobie potencjalne problemy rodzin, albo wiedzieli o nich: „Wiele razy mówiła: «Zostań w domu, ja już tego nie wytrzymam». [...] Nigdy nie groziła rozwodem, w życiu, co to, to nie. Co najwyżej: «Ja od tego oszaleję, ja tego nie wytrzymam». Ale nigdy nie oszalała, zawsze wytrzymywała" ${ }^{22}$.

Wyjaśnienia, dlaczego byli marynarze unikają tematu życia rodzinnego, trzeba zatem szukać gdzie indziej - w interpretacji powiązanych kręgów tematycznych. W niektórych przypadkach było to akcentowanie ich obecnego kontaktu $\mathrm{z}$ wnukami, kiedy indziej nacisk na to, że mężczyzna-marynarz materialnie zabezpieczał rodzinę ( $\mathrm{w}$ tamtym okresie przede wszystkim dzięki niedostępnym towarom pochodzenia zachodniego - ubraniom, kosmetykom, sprzętowi elektronicznemu - które uchodziły do pewnego stopnia za znak luksusu), ewentualnie, że żona mogła jeździć w podróże $\mathrm{z} \mathrm{nim}{ }^{43}$. Na podstawie wszystkich wypowiedzi i ich interpretacji proponowałabym następujące wyjaśnienie: byli marynarze nie mówią o swoich rodzinach (i ich życiu w czasowej izolacji od mężów i ojców) nie dlatego, że o problemie nie wiedzą, nie uświadamiają go sobie, czy też że ich nie on interesuje, ale właśnie przeciwnie - dlatego, że zdają sobie z niego sprawę, że czują pewnego rodzaju rozczarowanie. Starają się więc unikać tych wspomnień i realizują strategię racjonalizacji własnego postępowania (zabezpieczenie materialne, podróże), ewentualnie odwołują się do swego rodzaju „nieuniknioności”, „sytuacji bez wyjścia”: „Jak mówię, to było coś za coś. I żona wiedziała, że mąż idzie. Szedł do pracy. Jak montażyści chodzili do pracy. Szedł z Czech na Słowację, był tam czternaście dni. Ja też szedłem do pracy, ale szedłem do pracy na dłużej" ${ }^{\prime 4}$.

Byli i tacy, którzy ze względu na rodzinę porzucili zawód marynarza; ci, którzy tego nie zrobili czy nie zdołali, nie są gorszymi mężami czy ojcami. Po prostu nie potrafili zrezygnować z morza i pracy na morzu: „Gdybym twierdził,

42 Rozmowę z Milanem Bláhou przeprowadziła Lenka Krátká, 26 V 2010 r. Prywatne archiwum autorki.

43 Warunki podróży żon normowała umowa zbiorowa; członkowie rodzin pokrywali koszty drogi z/do portu i pewną opłatę za każdy dzień na statku.

44 Rozmowę z Jánem Jurcem przeprowadziła Lenka Krátká, 22 III 2010 r. Prywatne archiwum autorki. 
że za morzem nie tęskniłem, kłamałbym. Gdybym mógł, natychmiast bym na nie wrócił. Kiedy otwieram okno i słyszę huczenie jazu, to jakbym zachorował. A kiedy siedzę z wnukiem na schodach obok jazu w Doudlevcach [Doudlevce dzielnica Pilzna - przyp. tłum.] i słucham, jak woda płynie między kamieniami, jak się toczy i w szczególny sposób do mnie mówi, mam łzy w oczach. Brak mi tego morza" ${ }^{45}$. W pewnym uproszczeniu można by powiedzieć, że gospodarka niedoboru i ściśle strzeżone granice socjalistycznej Czechosłowacji były dobrym usprawiedliwieniem (i wytłumaczeniem) ich długotrwałej nieobecności w domu. Jakie wytłumaczenie znaleźliby dziś? Narratorzy, którzy nadal pracują na statkach morskich (u zagranicznych armatorów), tego problemu nie muszą rozwiązywać, bo ich rodziny już „się przyzwyczaiły”: „No i zostałem w zeszłym roku na święta. Pięć lat pod rząd nie byłem na święta w domu, więc w zeszłym roku na święta zostałem. [...] to już przyjmują. Bo wiedzą, że lepiej jest, kiedy jestem w domu od wiosny do jesieni" ${ }^{\prime 4}$.

Z przedstawionymi wyżej tematami częściowo związana jest także problematyka handlu na czarnym rynku. O ile bowiem marynarze chcieli materialnie i finansowo zabezpieczyć rodzinę, byli w znacznym stop-

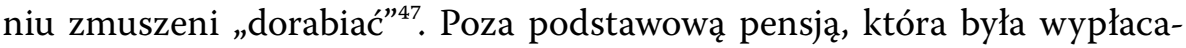
na $\mathrm{w}$ koronach, marynarz $\mathrm{w}$ czasie pobytu na statku miał do dyspozycji około 36o-46o USD na pół roku (zależnie od służbowego uszeregowania). Mógł je wykorzystywać na zakupy w kantynie na statku (papierosy, alkohol, gumy do żucia, kosmetyki męskie), lub w portach (ekwiwalentna suma

45 Josef Osoba, marynarz 1 klasy, e-mail wysłany Lence Krátkiej, 27 II 2010 r. Prywatne archiwum autorki.

46 Rozmowę z Milanem Bláhou przeprowadziła Lenka Krátká, 26 V 2010 r. Prywatne archiwum autorki.

47 Pensja marynarza nie przewyższała znacząco średniego wynagrodzenia w Republice Czechosłowackiej; dopełniały ją dodatki za pracę w nadgodzinach, w weekendy i w święta. Przy wypuszczeniu do domu marynarz zyskiwał zgodnie z prawem urlop i nadal wypłacano mu 50\% podstawowej pensji (przy czym możliwość dorabiania była bardzo ograniczona). Za każdy dzień na statku marynarz dostawał tzw. dodatek dolarowy, stopniowany w zależności od funkcji na cztery kategorie (w latach sześćdziesiątych o,7-2,2 USD na dzień, w osiemdziesiątych 3,0-4,6 USD na dzień). Jedna trzecia z tego była obowiązkowo wypłacana w tzw. bonach Tuzexu, które służyły do zakupów w kraju w sieci sklepów Tuzex (odpowiednik polskiej Baltony), gdzie można było dostać towary zagraniczne, L. Krátká, Českoslovacká námořní plavba očima československých námořníků. 1959-1989, Praha 2010, Fakulta humanitních studií Univerzity Karlovy, niepublikowana praca dyplomowa, s. 57-58. 
była wypłacana w walucie danego państwa). Aby móc kupować w krajach zachodnich, marynarze starali się gdzie indziej zaoszczędzić, czy dorobić, zazwyczaj w biednych krajach: najczęściej wspominany jest były Związek Radziecki, poza tym Kuba, Indie: „Na Kubie, tam było dobrze. No wszędzie tam, gdzie była bieda, to marynarzom było dobrze [...] A na Kubie tam było dobre, że tam nic nie dało się kupić. Nie trzeba było oszczędzać pieniędzy. I wszystko się dało sprzedać. Wszystko się dało spieniężyć. Wszystko. Wszelkie ubrania, stare ubrania, wszystko się dało sprzedać" ${ }^{48}$.

W tym kontekście interesujące jest nadal utrzymujące się przekonanie narratorów, że przy tego rodzaju handlu nie dopuszczali się niczego niezgodnego z prawem. Dowodzą tego także dokumenty byłej Służby Bezpieczeństwa (Státní bezpečnost, StB), która monitorowała tego rodzaju aktywność ${ }^{49}$.

O ile narratorzy wspominają jakieś własne interesy na czarnym rynku, podkreślają, że nie przesadzali z taką aktywnością, ewentualnie wskazują na przykłady innych kolegów: „Słyszałem, jak ktoś opowiadał anegdotkę, że na przykład, kiedy dawało się bieliznę do prania do pralni, to musieli jeździć ponad dwukrotnie, bo jedno auto wiozło dżinsy, a dopiero drugie wiozło bieliznę. A nad Murmańskiem na wzgórzu jest wielka rzeźba jakiegoś czerwonoarmisty, my nazywaliśmy go Alosza [rzeźba Aloszy z 1973 r., symbolizuje znaczenie Murmańska w Wielkiej Wojnie Ojczyźnianej - przyp. autorki]. I były tam chłopaki na jakieś te święta, no to kombinowali, jak te dżinsy dać na brzeg. To upletli ogromny wieniec i w tym wieńcu było kilka dziesiątek dżinsów. I że załoga m/s Košice niesie wieniec do tej rzeźby" ${ }^{50}$.

48 Rozmowę z Jánem Jurcem przeprowadziła Lenka Krátká, 22 III 2010 r. Prywatne archiwum autorki.

49 Służbę Bezpieczeństwa interesował szeroki wachlarz zagadnień - od problematyki gospodarczej, aż po zdrady małżeńskie; przestępstwa celne i nielegalny handel były monitorowane bardzo intensywnie. $Z$ punktu widzenia narratorów chodziło więc o stosunkowo niebezpieczną działalność, z czego być może nie zawsze zdawali sobie sprawę, Archiv Bezpečnostních slozek, teczka obiektowa nr 4147. Sami narratorzy kwestię tajnych współpracowników Służby Bezpieczeństwa w swych szeregach dziś raczej bagatelizują, czy też nie mówią o niej - być może wynika to z faktu, że żaden z narratorów nie był w zasadzie bezpośrednio pokrzywdzony przez Służbę Bezpieczeństwa i jej współpracowników, ale także aby ich profesja, z której są bardzo dumni, nie była oczerniana, L. Krátká, Československá námořní..., s. 69). Szczegółowa analiza dostępnych informacji z tej teczki obiektowej będzie częścią składową projektu „Historie podniku Československá námořní plavba”.

50 Rozmowę z Jindřichem Tesařem przeprowadziła Lenka Krátká, 5 V 2010. Prywatne archiwum autorki. 
Wszystkie wyżej przytoczone wspomnienia i ludzkie historie, niezależnie od tego, czy dotyczą pracy, czy życia prywatnego, kraju czy zagranicy, należy oczywiście analizować w kontekście komunistycznej Czechosłowacji (a więc życia w warunkach niesprawnej gospodarki, ograniczenia swobody poruszania się mieszkańców i wszechogarniającego braku wolności). Pogłębiona analiza losów tej grupy społecznej jest przedmiotem dalszych badań. Na podstawie przeprowadzonych rozmów można już jednak wysnuć pewne wnioski. Bardzo ważny wydaje się tu na przykład temat emigracji. Poglądy i wspomnienia narratorów wskazują, że o ile człowiek ma swobodę poruszania się, możliwość podróżowania, swobodnego wyjeżdżania i powrotu, zaczyna sobie intensywnie uświadamiać potrzebę posiadania domu, potrzebuje możliwości powrotu do swoich korzeni.

Przypomnijmy sobie istotny temat niniejszego artykułu, a więc (w uproszczeniu): praca kontra rodzina: narratorzy z jednej strony akcentują potrzebę posiadania rodzinnego fundamentu, z drugiej zaś jednak ci, którzy pracowali na morzu przez dłuższy czas, przyznają (chociaż nie bezpośrednio), że morze było dla nich co najmniej tak samo ważne jak rodzina. Czy chodzi tu o to, że morze ma „magiczną moc”? A może chodzi o to, że mężczyźni ci bez wolności (nawet ograniczonej i tymczasowej) nie potrafili się obejść? Czy takie zachowanie jest cechą typową dla mężczyzn pochodzących z kraju bez dostępu do morza, bez tradycji marynistycznej czy też w podobny sposób odczuwają wszyscy marynarze w każdym czasie? Pragnęłabym w samym zakończeniu swego artykułu otworzyć taką dyskusję, a raczej wezwać do badań komparatystycznych, o ile na gruncie polskim istnieje już (lub jest planowany) podobny program badawczy. Za szczególnie interesujące uważałabym badania komparatystyczne, skoncentrowane wokół zagadnień możliwości podróżowania, emigracji, warunków finansowych i warunków pracy marynarzy.

Tłumaczenie z języka czeskiego Katarzyna Uczkiewicz 
Lenka Krátká

"I was wondering if the sea is salty!" Czechoslovak Maritime Shipping Company

in the memories of Czechoslovakian sailors (1959-1989)
The author presents the outcomes of oral history research relating to the history of the Czechoslovak Maritime Shipping Company from 1959-1989 in the form of a case study. The interpretation of the accounts of seventeen former Czechoslovakian sailors focuses on two aspects: their professional and family lives. The author recognises that these two aspects of the sailors' lives were very often in conflict with each other, concluding that their work was often much more significant than their family life; that although they realised the problems that their families faced, they were unable to help by giving the work up to be with their families.

The text is supplemented with a methodological reflection that focuses on the issue of a researcher's emotional engagement to the research subject. Finally, the author presents thoughts on parallel and potential comparative studies between the lives of the Czechoslovakian sailors (from a country without direct sea access) and Poland (a country with a very rich maritime tradition). 